\title{
How Much Sunlight Does it Take to Disinfect a Boardroom? A Short History of Executive Compensation Regulation
}

\author{
IAN DEW-BECKER
}

CESIFO WORKING PAPER NO. 2379

CATEgORY 4: LABOUR MARKETS

AUGUST 2008

Presented at CESifo Venice Summer Institute 2008, Workshop on EXeCUTIVE PAy

\footnotetext{
An electronic version of the paper may be downloaded

- from the SSRN website:

- from the RePEc website:

- from the CESifo website:

www.SSRN.com

www.RePEc.org

www.CESifo-group.org/wp
} 


\title{
How Much Sunlight Does it Take to Disinfect a Boardroom? A Short History of Executive Compensation Regulation
}

\begin{abstract}
This paper reviews the history of executive compensation disclosure and other government policies affecting CEO pay, and as well surveys the literature on the effects of these policies. Disclosure has increased nearly uniformly since 1933. A number of other regulations, including special taxes on CEO pay and rules regarding votes on some pay packages have also been introduced, particularly in the last 20 years. However, there is little solid evidence that any of these policies have had any substantial impact on pay. Policy changes have likely helped drive the move towards more use of stock options, but there is no conclusive evidence on how policy has otherwise affected the level or composition of pay. I also review evidence from overseas on "Say on Pay," recently proposed in the US, which would allow nonbinding shareholder votes on CEO compensation. The experiences of other countries have been positive, with tighter linkages between pay and performance and improved communication with investors. Mandatory say on pay would be beneficial in the US.
\end{abstract}

JEL Code: J01, J08, J33, K22.

\author{
Ian Dew-Becker \\ Harvard University \\ Department of Economics \\ Littauer Center, 3rd Flr. \\ Cambridge, MA 02138 \\ USA \\ idew@fas.harvard.edu
}

Prepared for the CESifo Summer Institute conference on executive compensation in Venice, June 17, 2008. I acknowledge support from an NSF graduate research fellowship. I appreciate helpful comments from Bob Gordon, Naomi Hausman, David Laibson, and Rebecca Fitzpatrick, and the participants at the CESifo Summer Institute. 


\section{Introduction}

Over the last 15 years, there has been renewed public interest in executive compensation. Especially beginning in the early 1990's, there was substantial outcry over rising pay packages for CEOs while the wage of the average worker was stagnating. Piketty and Saez (2003) show that since the late 1970's, the income of the richest Americans has diverged from the rest of the population. At the same time, Dew-Becker and Gordon (2005) show that the income of nearly all American workers, with the exception of the top 10 percent, lagged average labor productivity growth. Moreover, the divergence between the pay of CEOs and the average worker was far larger in the US than in any other country.

Regardless of the cause of this divergence, it is not surprising that it brought enormous political pressure for change. By the early 1990's, executive pay packages looked especially unreasonable when compared to those in Japan, a country that, at the time, had far superior economic performance. Therefore, in 1992 Congress enacted two major changes to the way executive compensation is treated. First, mandatory disclosure of executive pay was expanded dramatically, with far more detailed explanations of precisely what executives are paid and why they are paid it. Second, the tax code was changed so that all pay above $\$ 1$ million that is not tied to performance is now deemed "excessive" and is not eligible to be deducted from corporate income for tax purposes. ${ }^{1}$

The 1992 laws are perhaps the best known changes in policy regarding executive pay, at least among economists. However, the government treatment of executive pay has changed drastically over a much longer period. This paper provides a short history of policies regarding executive pay since the 1930's. In particular, I look at disclosure rules, tax rules, and the effects of changes in legal liability. There has been substantial research on the determinants of executive pay but surprisingly little on the policies that are used to control pay. Throughout the paper, I try to note any available research on the effects of policy changes. It is evident, though, that much more work could be done. Policies that affect executive compensation are actively changing, with at least 5 major laws having been enacted over the past 16 years. We know surprisingly little about their effects. .

What will become clear is that the United States currently has a surprisingly sensible set of disclosure rules. The SEC has spent over 70 years fine-tuning the policies, and it is now difficult to find any major flaws that should be rectified. I will argue that the developments that have occurred in compensation disclosure policy should be emulated elsewhere.

The presence of good regulatory policy, however does not imply that corporate governance overall is perfect. Rather, there is probably a lot we could do to improve the performance of boards of directors. $^{2}$ While there is little solid evidence on the effects of

\footnotetext{
${ }^{1}$ The SEC also allowed shareholder proposals on executive compensation to be added to proxies. I discuss this change in section 5 below.

${ }^{2}$ See, for example, the work of Lucian Bebchuk.
} 
corporate governance on executive pay, it does not take a huge leap of logic to see why weak corporate governance might leave executive pay excessively high.

One recent proposal to improve governance is mandatory "Say on Pay." Under this plan, publicly traded companies would be required to put their CEO compensation plan up for a non-binding vote at each annual meeting. Research on the effects of similar policies in other countries finds generally positive results. I argue that the US would do well to adopt say on pay, and that the standard criticisms are not terribly convincing.

The remainder of the paper is organized as follows. In section 2 I review the history of disclosure rules, showing that they have followed a nearly continual trend towards more thoroughness. Section 3 discusses how various government policies have affected the composition of executive pay, rather than just its level. Section 4 examines corporate governance. In section 5 , I ask whether say on pay proposals are sensible and what effects we might expect them to have. Finally, section 6 concludes.

\section{Disclosure Rules}

\section{The Beginning of Mandatory Disclosure}

The first requirements for disclosure by publicly traded firms were enacted in 1933 with the Securities Acts. ${ }^{3}$ All firms making a new offering were forced to register with the Securities and Exchange Commission (SEC) and send out a prospectus detailing the financial condition of the firm. Firms listed on exchanges also had to send out proxy statements before annual meetings or shareholder votes. The proxy statement was intended to give shareholders the necessary information to make informed votes about any proposals. It had to contain information on the qualifications of any nominees for the board of directors, any transactions they have with the firm, and their holdings of company stock. Furthermore, companies could recover the profits if any insider bought and sold stock within a 6-month window (however, public firms not listed on an exchange - over the counter, or OTC firms - were exempt from this requirement). In other words, in the very first disclosure requirements, the SEC was already dealing with the possibility of directors acting in their own interests, rather than those of the shareholders. ${ }^{4}$

In 1938, the SEC first required firms to disclose executive compensation. The new proxies, along with the rules from 1933, began the systematic media scrutiny of executive pay. In 1942 for the first time, the SEC required companies to disclose executive pay in a table, rather than just in narrative form. The tabular disclosure was expanded also in 1952 to include pensions and deferred compensation. By moving to

\footnotetext{
${ }^{3}$ See Greenstone, Oyer, and Vissing-Jorgensen (2006) for an extensive explanation of these laws and subsequent amendments. My description relies on their work.

${ }^{4}$ La Porta, Lopez-de-Silanes, and Shleifer, 2006, study the cross-sectional relationship between disclosure laws, among others, and financial development in a large international sample. They find that greater disclosure is related to greater financial development along a number of dimensions.
} 
tables, the SEC was helping to increase the transparency of disclosure, even if the actual amount of information disclosed was the same. Just as with financial statements, the tabular disclosure is obviously much easier to grasp than a narrative. In particular, it allows easy comparisons across firms and keeps firms from obscuring facts with accounting jargon. However, by requiring only disclosure of specific types of pay rather than the total pay package, firms could disguise pay simply by using vehicles that were not required to be disclosed, such as perks. Moreover, tabular disclosure necessarily forces firms to oversimplify their pay packages. For example, investors are probably much more willing to pay a CEO a bonus when it is tied to some specific performance goal. Simple tabular disclosure does not allow a firm to make clear exactly how pay is determined. Throughout the history of disclosure regulations, the SEC has tried to balance transparency and detail.

\section{The 1960's and 70's}

The last major expansion of the firm coverage of disclosure rules was in 1964 . Essentially, it extended coverage to nearly all OTC firms. There is evidence that prior to this disclosure, much of securities fraud, at least in terms of the raw number of offenses, was concentrated in these relatively unregulated firms (see Greenstone, Oyer, and Vissing-Jorgensen, 2006, and Seligman, 1995). The majority of OTC firms did not even tell shareholders the names of the directors, let alone their qualifications or possible conflicts of interest. 30 percent of OTC firms did not even send out proxy statements before annual meetings. Greenstone, Oyer, and Vissing-Jorgensen also note that people at the time believed that firms did not list themselves on stock exchanges precisely so they could avoid the disclosure requirements. However, it is noteworthy that by severely limiting their disclosure, these firms probably opened themselves up to far higher risk of litigation than firms listed on exchanges (a topic to which I return below).

Greenstone, Oyer, and Vissing-Jorgenson (2006) provide one of the cleanest analyses of the effects of disclosure rules. Prior to 1964, two equally sized firms with identical financial characteristics could have totally different disclosure requirements simply depending on whether they were listed on an exchange or not. The 1964 rule changed that. Using a variety of methods, Greenstone, Oyer, and Vissing-Jorgensen (2006) find that the firms to which the new rules applied had substantial excess returns. During the 18 months over which the new rules were considered and passed, these firms had a 4 -factor alpha of 10 percent. ${ }^{5}$ If the rules helped solve an agency problem due to imperfect monitoring, then this value was largely newly created. On the other hand, it is possible that the rise in stock prices constituted simply a transfer of wealth from insiders to shareholders. The authors note that they cannot test this possibility. Nevertheless, it is clear that the effect is large and shareholders were left better off.

Throughout this period, the Internal Revenue Service (IRS) required that executives pay taxes on any perks that they received that were not available to all

\footnotetext{
${ }^{5}$ 4-factor alpha is a measure of excess returns after controlling for 4 aggregate risk factors; see Carhart (1997).
} 
employees of their firm. The rule, however, was not enforced until 1977. In that year, a line was added to corporate income tax returns requiring disclosure of management perks, but companies said that they did not have the information necessary to report the value of perks. In 1978, the SEC substantially expanded disclosure rules, requiring the summary compensation table in the proxy statement to cover all forms of compensation, including perks, contingent compensation, and expanded disclosure of the value of stock options and stock appreciation rights. The IRS then expanded its Audit Technique Handbook in 1979 to inspect perks more closely. ${ }^{6}$ McGahran (1988) studies these changes and finds that when perks became more expensive to executives due to the new tax treatment, they tended to shift compensation more towards salary.

\section{The Pendulum Swings Back}

By the late 1970's, essentially all major forms of compensation were being reported in tables. Perks were included in the summary compensation table, and any perk valued at more than $\$ 25,000$ (based on the incremental cost to the company) was reported in a footnote. But in 1983, the SEC turned on its heel and markedly reduced disclosure. The summary compensation table now only included cash compensation, and firms no longer had to report contingent compensation, interest on deferred compensation, or dividends paid on restricted stock (even though they still had to pay taxes on this money). Moreover, the number of officers covered by disclosure was limited, and perks below the value of \$25,000 no longer had to be reported anywhere. Essentially, prior to 1983, all compensation that would show up somewhere on financial statements (though aggregated with other data) was to be reported in the proxy statement. After 1983, this was no longer the case; there were substantial opportunities to obfuscate the true cost of compensating executives.

Between 1938 and 1982, the SEC followed a path of only increasing disclosure. Bebchuk and Hamdani (2006) note this same trend as a part of generally increasing Federal regulation of securities markets. Corporate law originated in state law, but through the $20^{\text {th }}$ century, the Federal government expanded its regulation of corporations as they became more national in character. In 1983 though, the SEC turned around and substantially reduced disclosure rules in the name of simplification, transparency, and reduced compliance burdens. This change fits with the general trend towards deregulation under President Reagan in the 1980’s.

\section{The Current Regime}

The current regime of disclosure rules began in 1992 with a complete overhaul of how executive pay is treated in proxy statements. Disclosure was expanded from the three most highly paid executives to the CEO and the other 4 most highly paid

\footnotetext{
${ }^{6}$ This section draws much from McGahran, 1988, who provides an extensive and clear explanation of the changes in the late 1970's.
} 
executives. ${ }^{7}$ Firms now had to report salary, bonus, perks, and long term compensation going back 3 years. The SEC added a performance chart to the proxy that compared the firm's stock return to a reasonable benchmark so that investors could see the relationship between pay and performance, and a compensation committee report was required to identify explicitly the performance measures used to determine pay and the general goals of the compensation package. In addition, a number of new tables were added to the proxy statement meant to disclose many of the vehicles that firms had been using to disguise the total value of pay. For example, firms had to disclose the value of retirement plans and severance packages over a certain threshold. ${ }^{8}$

Firms also had to begin to report the value of stock options granted, unlike under the 1983 rule when just the number of shares was reported. They had three choices: the Black-Scholes method, or calculating the potential value of the options assuming 5 or 10 percent annual stock appreciation. Murphy (1996) examines firms' reporting choices and finds that they tended to use whatever valuation method gave the smallest value for the options.

Lo (2003) studies the effect of the 1992 rule on stock returns. She considers firms that submitted comments to the SEC criticizing expanded disclosure, and assumes that those firms were the ones who likely had some sort of agency problem. That is, if they were against disclosure, it was probably because they had something to hide. She finds that these firms had excess returns of approximately 6 percent during the 3 month period over which the new rule was considered and saw improvements in returns on both assets and equity.

In 1993, Canada expanded disclosure in a manner similar to the US. Because there is so little direct evidence on the impact of disclosure in the US, studying other countries' experiences is critical. In Canada, firms were not only required to report current compensation, but also the previous three years. ${ }^{9}$ Park et al. (2001) and Craighead et al. (2004) study this change. Park et al. (2001) find that disclosure actually raises pay, which they argue is due to executives' increased bargaining power when they have better information about the pay of their peers. Craighead et al. (2004) argue, on the other hand, that Park et al. (2001) find increased pay because their sample of firms changes over time and because they do not properly control for the effects of accounting performance on pay. Craighead et al. (2004) use a subtler identification strategy, arguing that disclosure should have different effects on closely held versus widely held firms. In closely held firms, monitoring should be effective even in the absence of mandatory disclosure. Thus, they find that following disclosure, pay becomes more closely tied to performance in widely held firms.

\footnotetext{
${ }^{7}$ Disclosure was also extended somewhat to cover directors, though the disclosure is still not as extensive as it is for executives.

${ }^{8}$ The rule was slightly expanded in 1993. Previously, if an executive retired, his or her compensation was not reported in that year, encouraging the use of massive payments on the date of retirement. As of 1993, firms had to report the pay of any executive who left the firm but was among the 5 highest paid employees prior to leaving.

${ }_{9}^{9}$ This was also true in the US following 1992, but it was phased in so that no new information on, e.g., 1991, was ever reported.
} 


\section{The 2006 Rule}

The final change to disclosure occurred in 2006. After the SEC proposed new rules in January, it received 20,000 public comments, more than any other SEC proposal in history. The 1992 change garnered only 900 comments (still more than the 1983 and 1978 rules combined). The 2006 rule has been viewed as a huge change in how pay is reported, even though it looks outwardly very similar to the prior regime, in the sense that the summary compensation table is retained, along with familiar tables detailing options grants, pensions, etc. The major difference in the 2006 rule, as noted by Brown (2007), is that it is "principles-based" rather than "rule-based." That is, the SEC wants every component of compensation to be disclosed, regardless of whether there is a specific provision for it. Firms are supposed to disclose thoroughly what their total liabilities are to the CEO, including severance packages, pensions, and deferred compensation. Extending principles-based disclosure to the proxy statement fits with recent general trends, including the Financial Accounting Standards Board's new rules for stock option valuation (see below). Furthermore, the 2006 rule makes clear that all potential payments to executives are to be disclosed, not just those that were paid out in the prior year.

To an economist, the 2006 rule looks like a triumph of common sense. It is designed to tell investors the change in what the firm owes an executive over the past year. For example, in the past, firms were required just to report payments from long term compensation packages. Now they are required to report the change in what they actually owe to the executive. The SEC also pushed much harder for plain English disclosure of what the firm is actually trying to accomplish with its pay package, rather than allowing firms to continue their use of complex accounting terminology. This brings compensation disclosure in line with the financial statements, which require the same sort of plain English reporting.

To be more specific (though by no means exhaustive), the new rules expanded disclosure in the following ways: ${ }^{10}$

- All components of compensation must be measured in dollar terms

- Add a new table summarizing the pay of directors

- Deferred compensation is now included in the summary compensation table

- Disclosure of severance and retirement packages is substantially enhanced

- Add disclosure of specific targets and the range of potential payouts for incentive plans

- Perks must be disclosed if they are worth more than $\$ 10,000$ (as opposed to $\$ 50,000$ as of 1992 )

\footnotetext{
${ }^{10}$ Brown, 2007, has a useful table listing the changes from the 1992 to the 2006 rule.
} 
- “All other compensation,” which includes components of pay not included in salary, bonus, or stock, must be disclosed in a separate table listing any individual component worth more than $\$ 10,000$

- Eliminate flexibility in disclosure of the value of options (firms have to follow the current financial accounting standard - the Financial Accounting Standards Board's rule 123R)

- When options are repriced, the incremental change in their value is reported in the proxy, instead of treating them as new grants (or not reporting them at all) as in the past

As noted above, these changes are all designed to allow investors to see the total amount of money that can potentially be paid to executives. The changes to reporting for severance and retirement packages are possibly the most important. Firms are now required to exhaustively list the possible payments if executives are terminated or there is a change in control. They also have to explain precisely what executives stand to receive in annual benefits from retirement plans. Previously, these two types of packages were what caused some of the largest outcries because they were often only revealed after executives were fired. For example, Disney had to spend millions of dollars fighting off a lawsuit that arose almost entirely due to a severance package paid to an executive who worked for only a year.

Bebchuk and Jackson (2005) find that, prior to the 2006 rule change, substantial amounts of compensation were being effectively hidden in retirement plans. The median CEO had a pension worth twice what they earned in salary during their entire tenure. This amount is seems considerable when one considers that while salary constitutes less than half of total compensation, it nevertheless comprises the majority of cash compensation. Bebchuk and Jackson (2005) also find that if previous studies had included the value of pensions in total compensation, they would have found pay to be far less connected to performance. Moreover, by paying CEOs through pensions, firms are able to avoid certain tax liabilities associated with salaries over $\$ 1$ million. ${ }^{11}$

There is as yet little research on the results of the 2006 changes. Beucler and Domat-Connell (2007), however, provide a review of investor opinions on the changes that gives at least anecdotal evidence on how disclosure has changed in practice. In some respects, they are optimistic. They find that disclosure is genuinely more extensive, with the disclosure of retirement benefits and director pay being two of the more effective improvements.

On the other hand, they find that firms still are not being as transparent as the SEC had predicted in the text of their 2006 rule. The Compensation Discussion and Analysis (CD\&A), is one major area of concern. While the SEC encouraged plain English disclosure and had envisioned the CD\&A only requiring 1,000 words, the median in 2007 was 4,726 words long, according to Beucler and Domat-Connell (2007). Moreover, they do not see it as in any way transparent to the average investor. An important question, though, is whether the length and opacity of the CD\&A is due to

${ }^{11}$ See the discussion of IRC section $162(\mathrm{~m})$ in section 3 below. 
firms trying to mislead investors or simply because firms are being careful due to the new liability associated with the CD\&A which I discuss below.

The other major shortfall that Beucler and Domat-Connell (2007) find in the 2007 proxy statements involves the disclosure of the value of equity compensation. As noted above, the SEC now requires principles-based disclosure of equity compensation, rather than requiring a single valuation method, but Beucler and Domat-Connell (2007) find that 54 percent of companies do not report their valuation methodology. ${ }^{12}$

In the end, it is clear that the new rule is a major step in the right direction, and that disclosure now covers all changes in liabilities to the CEO (including both current compensation and expected future payments). Nevertheless, as is common with new standards, some guidance from the SEC is probably necessary in order to help clarify expectations.

\section{Laws Affecting the Composition of Pay}

Around the same time that the SEC was decreasing mandatory disclosure, the Congress passed the Deficit Reduction Act of 1984. This law included a new set of taxes on severance packages. While severance packages were not enormously common at that time, congress acted to limit their use by limiting when they could be deducted from corporate income taxes and imposing a 20 percent excise tax on any severance package deemed "excessive." ${ }^{13}$ The technical definition of excessive here turned out to be three times average annual pay over the previous 5 years. I have been unable to find any research on the effects of this law, but the literature seems to agree that if anything, this new law actually encouraged the use of severance package (see, e.g. Jensen, Murphy, and Wruck, 2005). It was interpreted as a congressional endorsement of packages up to three times annual pay as "reasonable."

In 1993, again, just after a change in disclosure rules, Congress passed a major change to the tax code. A new section, 162(m), was added to the Internal Revenue Code (IRC). It says that all compensation over \$1 million that is not performance-based is deemed excessive and does not qualify to be deducted from corporate income. For income to qualify as performance-based, it has to be associated with specific targets with a horizon of at least 12 months, be approved by a compensation committee composed of at least two independent directors, and be put up for a shareholder vote. ${ }^{14}$

\footnotetext{
${ }^{12}$ However, they do not say whether they looked for a description of the valuation methodology in the 10$\mathrm{k}$. Since valuation of equity awards is now supposed to be consistent across the proxy and financial statement, it seems possible that firms just list their valuation methodology once in the financial reports.

${ }^{13}$ Note that the 20 percent tax is not a marginal tax. That is, it applies to the full value of the severance package only if it is above the limit. So if an executive has a $\$ 1$ million salary, then he pays no tax on a $\$ 3$ million severance package, but would pay $\$ 600,000$ on a $\$ 3,000,001$ package, netting him only $\$ 2.4$ million.

14 “Independent" was defined as more than not being an employee of the firm, but also not receiving any pay from the company for, e.g., a consulting relationship.
} 
The history of changes in policies related to executive compensation disclosure suggests that the rules do not just come out of thin air. In general, they are in response to encouragement from parts of the investment community. The changes we observe in 1992 had been endorsed explicitly by institutional investors. For example, as of 1993, the New York City Employees’ Retirement System, a multi-billion dollar pension fund, pushed for companies in which they invested to have a majority of their boards made up of independent directors, nominating and compensation committees that were fully independent, and a separate chairman and CEO (see Dodell, 1993).

Dodell (1993) also cites statements by the California Public Employees' Retirement System (CALPERS). CALPERS supported legislation similar to what was actually enacted in 1992. Specifically, it pushed for better disclosure and governance, but did not advocate that the government try to determine what constituted "reasonable" pay. It also argued that tax increases, like 162(m) would just come out of corporate profits. ${ }^{15}$

Firms that pay salaries less than $\$ 1$ million have strong incentives to shift towards performance-based pay, which should be a positive development, and they pay no extra taxes. On the other hand, the vast majority of firms now pay salaries above $\$ 1$ million. The tax still makes incentive-based pay relatively cheap, but firms are also paying a large amount of new taxes, which come out of profits. Even if firms are willing to pay salaries above \$1 million, though, 162(m) should still have an effect since a dollar of compensation paid as salary is more expensive to a corporation than a dollar paid that is performance-based.

A number of authors have studied the effects of the 1992 tax and disclosure changes. Vafeas and Afxentiou (1998) find that after 1992, compensation committees included noticeably fewer insiders, and compensation seems to be more closely tied to performance. These two effects are to be expected both from the 162(m) and the SEC rule. Perry and Zenner (2001) confirm that pay was increasingly sensitive to performance. They also say that firms paying salaries slightly above $\$ 1$ million prior to 1992 tended to reduce them after, but that firms paying higher salaries were largely unaffected.

The legal and consulting community, to some extent, has argued that $162(\mathrm{~m})$ is not nearly as stringent as it sounds. First, companies and executives had a one-time opportunity to avoid tax charges by shifting income from 1993 (when the law first applied) into 1992. Moreover, by awarding salary but then deferring payment until retirement, firms could completely avoid the $\$ 1$ million cap (see, e.g., Kroll, 1998). ${ }^{16}$ The rules about pay being tied to performance are also easily skirted. Suppose the compensation committee says that the CEO receives 1 percent of total sales above some level as her bonus. If, at the end of the year, they try to increase the bonus for some other

\footnotetext{
${ }^{15}$ In general, institutional investors very consistently say that they do not want to interfere with the determination of "reasonable" salaries. Rather, they push for independent boards and strong incentives for CEOs.

${ }^{16}$ Nusbacher and Johnston, 1993, note that deferred compensation may not be very attractive to corporations. The compensation shows up on current financial reports but does not provide a tax deduction until it is paid. Moreover, they have to pay taxes on all of the investment earnings.
} 
subjective reason, then the entire bonus no longer counts as performance-based, and the firm pays taxes on it. Suppose, on the other hand, the firm says that its official policy is to set the bonus to 2 percent of sales, but then it just revises the bonus downward at will to meet whatever value it deems appropriate. This alternative package will then likely pass muster with IRS. So even though 162(m) gave firms greater incentive to use performance-based pay, it also gave them incentive to make the targets relatively easy to achieve (see Salwen and Laarman, 1993). That said, a firm's pay package will look suspicious to both the IRS and investors if it involves a massive payout for performance that is then revised downwards every year, so there are limits to this strategy. ${ }^{17}$

Regardless of the ways that firms can minimize the effects of 162(m), it certainly contributed to the enormous rise in the use of stock options. Some firms have even made standing offers to executives that allow them to trade salary for (non-qualified) option grants. The tax treatment of stock options was made even more attractive with the Taxpayer Relief Act of 1997 and the IRS Restructuring and Reform Act of 1998. These acts lowered the maximum capital gains tax rate from 28 to 20 percent, and this had an immediate impact on executive pay. Under the new laws, if an executive receives an incentive-based stock option (also known as a qualified option), they never pay income taxes on it as long as they do not exercise it within two years of the grant date. The entire value is treated as a capital gain. This makes qualified options much more attractive to executives, and even more so after the further reduction in capital gains tax rates that occurred in 2003.

\section{Corporate Governance: “Care and Loyalty”}

\section{External Governance}

While changes in the 1990's affected the composition of pay, changes in the late 1980's may have had a substantial effect on its level. Following the Supreme Court's decision in CTS v. Dynamics Corp., states were allowed to write laws making hostile takeovers much more difficult. ${ }^{18}$ Delaware, the state in which more than half of firms are incorporated, enacted its anti-takeover legislation in 1988. This was a business combination law that worked mainly to inhibit leveraged buyouts. Bertrand and Mullainathan (1999) provide an extensive discussion of the history of these laws. They

\footnotetext{
${ }^{17}$ Kroll, 1998, and Nusbacher and Johnston, 1993, discuss issues associated with 162(m) from the perspective of the legal and compensation consulting communities.

${ }^{18}$ Bertrand and Mullainathan, 1999, provide a detailed description of the various laws and their history. Until fairly recently, most corporate law operated at the state level. Corporations exist as creations of states, rather than the federal government. Therefore, a very large part of the statutory and case law originates in the states.
} 
then exploit the cross-state variation in the laws to measure their effects on executive pay. They find that pay tended to rise in firms affected by the new laws.

Interestingly, they also find a rise in pay for performance in these same firms. This is consistent with the hypothesis that because agency problems increased, firms had to increase the incentives for good performance. Moreover, because compensation became riskier, its expected value had to rise in order for executives to get the same value. What is worrisome, however, is that the increase in pay for performance only occurred in firms with a large shareholder. Firms without a large shareholder must have then had an increase in agency problems without an attendant change in pay structure to mitigate them. ${ }^{19}$ The changes in executive pay following changes in how easy it is to buy out firms is an example of the market for corporate control acting as a monitoring mechanism (see Jensen, 1993)

The Sarbanes-Oxley Act of 2002 covered a diverse set of issues related to corporate governance. A few of its provisions directly affect executive compensation. First, it disallows loans from corporations to their executives, a type of compensation heavily criticized by Bebchuk and Fried (2004). Second, since the CEO and Chief Financial Officer must now personally certify financial statements, if those statements are materially revised, the CEO is required to give the company back 100 percent of his or her performance based compensation. Third, it requires that the board be made up of a majority of independent directors, and that the nominating and compensation committees be entirely independent. At the same time, the three major stock exchanges, the NYSE, NASDAQ, and AMEX, made their definitions of independence more stringent. The independent directors on the board are also now required to meet in executive session without the insiders at least once a year. These changes further enhance the rules applying to compensation committees in 162(m).

Chhaochharia and Grinstein (2006) study the effects of the provisions of Sarbanes-Oxley related to board independence on CEO compensation. They find that firms that were affected by this policy decreased compensation paid to their executives by 10 to 25 percent more than the change in pay by firms that were unaffected. Their analysis is one of the few available differences-in-differences studies of executive pay. Interestingly, they find that the majority of the decline in pay came from options, rather than cash. This implies that rather than options being used as a way to solve agency problems, if anything, they were used to inflate pay.

One of the major concerns in the comments to the SEC about the 1992 and 2006 rules was that it could open the board of directors to new kinds of lawsuits. In particular, firms were worried that they could be sued over the content of the compensation committee report if it contained even a minor mistake. In the 2006 revised regulations, the compensation committee report was somewhat downsized and replace with the "Compensation Discussion and Analysis (CD\&A)." Since the CD\&A is officially filed

\footnotetext{
${ }^{19}$ Shleifer and Vishny, 1986, first showed the relationship between large shareholders and the quality of corporate governance.
} 
with the SEC, it could conceivably be used as part of a lawsuit. ${ }^{20}$ Firms also worried that the increased disclosure might bring more frivolous lawsuits and that it might force them to reveal trade secrets. The same sort of concerns arose around the time Sarbanes-Oxley was passed. These concerns seem to have been unfounded, at least with relation to executive pay. Over the years, it has proven essentially impossible to sue corporations over pay packages. The new rules, in particular the compensation committee report, the required independence of the compensation committee, and the requirement in 162(m) that pay packages be approved by shareholders, make suits over executive pay even less likely to succeed than in the past. ${ }^{21}$ Moreover, the Private Securities Litigation Reform Act of 1995 made it more difficult for shareholders to sue firms, thus weakening even further the power of shareholders. ${ }^{22}$

The fiduciary duties of boards of directors can be divided into a duty of care and a duty of loyalty. ${ }^{23}$ When shareholders sue corporations over pay packages, they generally allege a violation of these fiduciary duties. The duty of loyalty says that directors must act in the best interests of the shareholders, rather than themselves. The duty of care says that directors must take due care in their decisions, gathering all relevant information and keeping abreast of all developments. Under a principle called the business judgment rule, courts are generally unwilling to question the decisions that boards make; rather, they will only look at the process at which the board arrived at the decision. As long as the process looks to have been duly deliberative and the board had no personal stake in the decision, courts will not question whether it was actually a good idea.

The combined effect of the SEC's 1992 and 2006 rules, IRC section 162(m), and Sarbanes-Oxley is to make all three types of claims more difficult than in the past. Because the compensation committee is now fully independent and the definition of independence is more strict, duty of loyalty claims are more difficult. Outside directors are generally given the benefit of the doubt with relation to self-dealing, whereas the burden of proof can be on inside directors to prove that they are not violating the duty of loyalty. The compensation committee report also makes duty of care claims more difficult than in the past. When the committee explicitly explains its motivation for the pay package, it is essentially showing that it took care in determining pay. Finally, because many pay packages are subject to shareholder approval, courts are unlikely to rule them wasteful. The logic is, if a reasonable person would not approve of this pay package, the definition of waste, then why would the shareholders have voted for it? Whether this logic makes sense (many shareholders probably do not read proxies carefully, and many do not even vote at all), it is the current state of affairs in the courts.

\footnotetext{
${ }^{20}$ This is as opposed to the compensation committee report, which is only "furnished,” which opens firms to less risk of liability.

${ }^{21}$ See, for example, the discussion in Olson, Mueller, and Rogers, 1993.

${ }^{22}$ Johnson, Kasznik, and Nelson, 2000, however, find that for a sample of high-technology firms, the PSLRA increased the market value of firms most likely to be involved in securities litigation. They note, however, that the benefit of limiting litigation is weaker when other governance mechanisms are also weaker.

${ }^{23}$ This section draws heavily on Pinto and Branson, 2004.
} 


\section{Say on Pay}

In recent years, there has been an increased movement within the ranks of corporate governance activists, institutional investors, and even legislatures, for corporations to accept "Say on Pay" rules. In general, shareholders cannot directly submit resolutions for a vote at a firm's annual meeting. In 1992, the SEC expanded the list of allowed types of resolutions to include those regarding executive compensation, which would include say on pay.

Standard say on pay rules require that companies submit executive compensation packages to the shareholders for a nonbinding advisory vote. As of the writing of this article, a measure has passed the House of Representatives, but has not yet come up for a vote in the Senate. It is supported by both US presidential candidates, and was in fact introduced by the Democratic nominee, Barack Obama (Ferri and Maber, 2007).

Even though say on pay is not yet mandatory, there has been a recent push among institutional investors to force companies to accept it. In 2007, 51 such proposals came up for votes, getting an average of 43 percent of shareholders voting in favor. As of May 6 of this year, 30 more proposals were voted on, drawing nearly identical support (Tse, 2008). In general, companies have been strongly against these proposals. Their main argument is that companies will no longer be able to attract the best talent because they will have to keep salaries low. Supposing this is true, it simply means that we should mandate say on pay for all companies. That way no individual firm will be at a disadvantage.

Our theoretical understanding of the effects of say on pay rules is very limited. The closest model is probably that of Singh (2007), who argues that firms may tailor their pay packages in order to signal that they are responsible. Alternatively, they might be able to signal their quality using the adoption of a say on pay measure. For example, suppose say on pay has the cost that it keeps a firm from hiring the very best CEOs, but it also keeps boards from overpaying their CEO. In that case, all boards would find it somewhat costly to adopt say on pay, but the boards who were the most beholden to the CEO would find it most costly, and hence we might find a separating equilibrium.

In terms of empirical results, the say on pay measures are so new that we only have very limited evidence. Johnson and Shackell (1997) study a related rule change from 1992. In that year, the SEC expanded the list of topics about which shareholders make submit proposals that can come up for a vote at the annual meeting. These sorts of proposals are often related to corporate governance, but the board can block any proposal that relates to the firm's “ordinary business." In 1992, the SEC stated that the ordinary business exclusion no longer related to executive compensation. Johnson and Shackell (1997) study proposals relating to executive compensation from 1992 to 1995. They find no evidence that these proposals have any effect on the level of pay. However, they do find that proposals relating to the independence of the compensation committee, in 
particular those submitted by institutional investors, often do lead to changes in the independence of that committee. ${ }^{24}$

Deane (2007) examines the results of mandatory say on pay in other countries. Five countries, the UK, Netherlands, Australia, Sweden and Norway, have instituted mandatory say on pay. In the Netherlands, Sweden and Norway, the say on pay votes are binding, unlike in the UK, Australia, and the proposed rule for the US where the votes are simply advisory. Thus far, very few compensation proposals have been rejected. The rejection in the UK of GlaxoSmithKline's package in 2003 has been widely noted since it led to the replacement of the entire compensation committee, but only four more packages have been rejected since then. In the Netherlands, Australia and Sweden, no packages have been rejected yet, though a few have received dissent nearing the 50 percent mark.

However, the simple fact that packages are not being rejected obviously doesn't mean that the new rules have had no effect. On the contrary, surveys across the five countries find that investors seem generally happy with the results of the new rules. In particular, Deane (2007) cites a number of studies finding that investors see pay as being more connected to performance. More importantly, there seems to be much better communication between boards and investors.

A survey by Deloitte and Touche (2004) finds that 60 percent of investors think that the extent to which companies confer with investors has increased "to a large extent," and 100 percent of those surveyed believed that communication had improved at least somewhat. However, UK investors still desire better disclosures. The quantity of information disclosed in the UK, as in the US, is substantial. At least according to investors, there are substantial costs to digesting all of the disclosures. Moreover, the policy that UK investors find most important in affecting compensation plans is the shareholder vote, rather than disclosure, even though the votes are nearly uniformly positive.

The only study that has so far applied state of the art empirical techniques to find the effect of say on pay on compensation is Ferri and Maber (2007) who look at executive pay in the UK from 2000 to 2007. Across a variety of specifications, they find that pay has become more sensitive to performance, especially negative performance. However, they find no evidence at all that say on pay has reduced the level of pay - if anything, pay may have risen somewhat (though if executives' pay becomes more risky, then its value to them falls).

The general results of mandatory say on pay in other countries can thus be summarized as follows. Compensation packages are rejected extremely rarely, largely owing to improved communication between investors and board members. Furthermore, pay becomes more connected to performance, but its level does not fall at all. Thus, as Deane (2007) notes, some of the major concerns about say on pay in the US may be

\footnotetext{
${ }^{24}$ Johnson and Shackell, 1997, also cite Karpoff, Malatesta, and Walkling, 1996, who find that in the 1980 's, shareholder proposals related to corporate governance led to no improvement in corporate governance or performance.
} 
unfounded. Large shareholders do not tend to vote on compensation packages based on their size, but rather on their composition. So it is unlikely that firms would no longer be able to attract talent and pay them at market rates. Moreover, the voting process has not been radicalized. That is, votes on compensation packages have not thus far been used as levers by special interest groups.

\section{Conclusion}

This paper summarizes the development of the rules and regulations that have direct and indirect effects on executive compensation. With only a limited exception, namely backtracking in 1983, the path has been towards greater disclosure of both pay and possible conflicts of interest. Pay disclosure has also become clearer and much more thorough over time. It is actually difficult to find any major flaws in the current rules governing how executive pay is disclosed. The point that we have now arrived at in disclosure is a combination of rule-based and principle-based disclosure. There is a large set of tables that firms have to fill in, but the general rule is that they need to disclose any potential payments to executives. As long as this is carried out in good faith, there is no reason to think that investors would be uninformed.

The remaining question then revolves around corporate governance, which covers an enormous range of issues. This paper summarizes the subset of those issues most closely related to executive pay. The general finding is that when governance improves, stock prices go up and executive pay seems both to fall and to become more sensitive to performance. The major limit in governance at this point seems to be that directors are still too insulated from shareholders. Even if a director is completely independent, he/she may be more interested in keeping a seat on the board than doing what is in the best interests of the shareholders. That is, directors may still care more about the happiness of the nominating committee than that of the shareholders.

Say on pay is one way to rectify problems with governance. The rules in Sarbanes-Oxley mandating fully independent nominating and compensation committees are also a step in the right direction. By keeping the nominating fully independent, directors need not worry about angering the CEO and then losing their seat. A further step would be to strengthen the definition of independence.

All of that having been said, the first thing we need is more research on what effects government policies actually have. There are numerous proposals for how to improve corporate governance and reform executive compensation, but without knowing what effects past policies have, we cannot hope to make good plans for the future. 


\section{References}

Bertrand, Marianne, and Sendhil Mullainathan 1999. "Corporate Governance and Executive Pay: Evidence from Takeover Legislation.” Mimeo, November, 1999.

Bebchuk, Lucian A. and Jessie Fried, 2004. Pay Without Performance: The Unfulfilled Promise of Executive Compensation. Harvard University Press: Cambridge. and Assaf Hamdani, 2006. "Federal Corporate Law: Lessons from History." Columbia Law Review, 106, pp. 1793-1839. and Robert J. Jackson, Jr., 2005. “Executive Pensions.” Journal of Corporation Law, 30(4) pp. 823-855.

Beucler, Erik and Jack Dolmat-Connell, 2007. "Pay Disclosure Rules: Has More Become Less?” The Corporate Board, 28(165) pp. 1-5.

Brown, Gary M., 2007. PLI's Guide to the SEC's Executive Compensation and Related Party Transaction Disclosure Rules. Practicing Law Institute: New York.

Cai, Jie and Ralph A. Walkling, 2008. “Shareholders' Say on Pay: Does It Create Value?” Mimeo, February, 2008.

Carhart, Mark, 1997. “On Persistence in Mutual Fund Performance.” Journal of Finance, 52(1), pp. 57-82.

Cagney, Lawrence K. and Daniel R. Brandhorst, 1993. "SEC Acts to Expand the Scope of Executive Compensation Disclosure Rules.” In Executive Compensation Reporting 1993, Keller, Stanley and John F. Olson, eds. Practicing Law Institute, New York.

Chhaochharia, Vidhi and Yaniv Grinstein, 2006. "CEO Compensation and Board Structure.” Mimeo (forthcoming in The Journal of Finance).

Craighead, Jane, Michel Magnan and Linda Thorne, 2004. “The Impact of Mandated Disclosure on Performance-Based CEO Compensation.” Contemporary Accounting Research, 21(2).

Deane, Stephen, 2007. "Say on Pay: Results From Overseas.” The Corporate Board, 28(165), pp. 11-18.

Deloitte \& Touche, LLP. 2004. "Report on the Impact of the Directors' Remuneration Report Regulations.” Deloitte, research report. 
Dew-Becker, Ian and Robert J. Gordon, 2005. "Where Did the Productivity Growth Go? Inflation Dynamics and the Distribution of Income.” Brookings Papers on Economic Activity, 38(2), pp. 67-150

Dodell, Sue Ellen, 1993. "Experience Under the New Rules: Investment Community Perspective.” In Executive Compensation Reporting 1993, Keller, Stanley and John F. Olson, eds. Practicing Law Institute, New York.

Ferri, Fabrizio and David Maber, 2007. "Solving the Executive Compensation Problem through Shareholder Votes? Evidence From the UK.” Mimeo, November, 2007.

Greenstone, Michael, Paul Oyer, and Annette Vissing-Jorgensen, 2006. "Mandated Disclosure, Stock Returns, and the 1964 Securities Acts.” The Quarterly Journal of Economics, 121(2), pp. 399-460.

Jensen, Michael C., 1993. "The Modern Industrial Revolution, Exit, and the Failure of Internal Control Systems.” Journal of Finance, 48(3), pp. 831-880.

, Kevin J. Murphy, and Eric G. Wruck, 2005. "CEO Pay...and how to fix it.” Harvard Business School NOM Research Paper No. 04-28, March, 2005.

Johnson, Marilyn F., Ron Kasznik, and Karen K. Nelson, 2000. “Shareholder Wealth Effects of the Private Securities Litigation Reform Act of 1995." Review of Accounting Studies, 5(3), pp. 217-213.

and Margaret B. Shackell, 1997. "Shareholder Proposals on Executive Compensation.” Mimeo, April, 1997.

Kroll, Arthur H., 1998. Compensating Executives. CCH Incorporated: Chicago.

Lo, Kin, 2003. "Economic consequences of Regulated Changes in Disclosure: The Case of Executive Compensation." Journal of Accounting and Economics, 35, pp. 285-314.

La Porta, Rafael, Florencio, Lopez-de-Silanes, and Andrei Shleifer. 2006. "What Works in Securities Laws?” The Journal of Finance, 61(1), pp. 1-32.

McGahran, Kathleen T. 1988. "SEC Disclosure Regulation and Management Perquisites.” The Accounting Review, 63(1), pp. 23-41.

Murphy, Kevin J. 1996. "Reporting Choice and the 1992 Proxy Disclosure Rules." Journal of Accounting, Auditing, and Finance, 11(3), pp. 497-515.

Olson, John F., Ronald O. Mueller, and Arthur M. Rogers, III, 1993. “The Board Compensation Committee Report on Executive Compensation: The Effect on the 
State Law Fiduciary Duty of Directors.” In Executive Compensation Reporting 1993, Keller, Stanley and John F. Olson, eds. Practicing Law Institute, New York.

Park, Yun W., Toni Nelson and Mark R. Huson, 2001. "Executive Pay and the Disclosure Environment: Canadian Evidence.” The Journal of Financial Research, 24(3), pp. 347-365.

Piketty, Thomas and Emmanuel Saez, 2003. "Income Inequality in the United States, 1913-1998.” Quarterly Journal of Economics, 118(1), pp. 1-39.

Salwen, Robert and Linda M. Laarman, 1993. "The Effect of the New Proxy, Tax, and FASB Rules on Executive Compensation.” In Executive Compensation Reporting 1993, Keller, Stanley and John F. Olson, eds. Practicing Law Institute, New York.

Seligman, Joel, 1995. The Transformation of Wall Street, Northeastern University Press: Boston.

Singh, Ravi, 2006. "Board Independence and the Design of Executive Compensation." Mimeo, September, 2006.

Tse, Tomoeh Murakami, 2008. “'Say-on-Pay’ Movement Loses Steam.” The Washington Post, May 6, 2006, pg. D1.

Vafeas, Nikos and Zaharoulla Afxentiou, 1998. “The Association Between the SEC's 1992 Compensation Disclosure Rule and Executive Compensation Policy Changes.” Journal of Accounting and Public Policy, 17(1) pp. 27-54. 


\section{CESifo Working Paper Series}

for full list see www.cesifo-group.org/wp

(address: Poschingerstr. 5, 81679 Munich, Germany, office@cesifo.de)

2317 Michael Hofmann, Gerhard Kempkes and Helmut Seitz, Demographic Change and Public Sector Budgets in a Federal System, May 2008

2318 Paul De Grauwe, Macroeconomic Modeling when Agents are Imperfectly Informed, June 2008

2319 Johann K. Brunner and Susanne Pech, Optimum Taxation of Inheritances, June 2008

2320 Thomas Eichner and Marco Runkel, Corporate Income Taxation of Multinationals in a General Equilibrium Model, June 2008

2321 Rainald Borck and Matthias Wrede, Subsidies for Intracity and Intercity Commuting, June 2008

2322 Patricia Apps and Ray Rees, Testing the Pareto Efficiency of Household Resource Allocations, June 2008

2323 Amihai Glazer, Vesa Kanniainen and Panu Poutvaara, Firms' Ethics, Consumer Boycotts, and Signalling, June 2008

2324 Claudia M. Buch, Jörg Döpke and Kerstin Stahn, Great Moderation at the Firm Level? Unconditional vs. Conditional Output Volatility, June 2008

2325 Helmuth Cremer, Philippe De Donder, Dario Maldonado and Pierre Pestieau, Forced Saving, Redistribution and Nonlinear Social Security Schemes, June 2008

2326 M. Hashem Pesaran and Paolo Zaffaroni, Optimal Asset Allocation with Factor Models for Large Portfolios, June 2008

2327 Harald Badinger and Peter Egger, Horizontal versus Vertical Interdependence in Multinational Activity, June 2008

2328 Jan K. Brueckner and Harris Selod, A Theory of Urban Squatting and Land-Tenure Formalization in Developing Countries, June 2008

2329 Paolo M. Panteghini, Corporate Debt, Hybrid Securities and the Effective Tax Rate, June 2008

2330 Guglielmo Maria Caporale, Juncal Cuñado and Luis A. Gil-Alana, Modelling Long-Run Trends and Cycles in Financial Time Series Data, June 2008

2331 Avi Ben-Bassat and Momi Dahan, Social Identity and Voter Turnout, June 2008 
2332 Martin R. West and Ludger Wößmann, "Every Catholic Child in a Catholic School”: Historical Resistance to State Schooling, Contemporary Private Competition, and Student Achievement across Countries, June 2008

2333 Erkki Koskela and Panu Poutvaara, Outsourcing and Labor Taxation in Dual Labor Markets, June 2008

2334 Philippe Choné and Laurent Linnemer, Optimal Litigation Strategies with Signaling and Screening, June 2008

2335 Albert Solé-Ollé and Pilar Sorribas-Navarro, Does Partisan Alignment Affect the Electoral Reward of Intergovernmental Transfers?, June 2008

2336 Antonio Cabrales and Piero Gottardi, Markets for Information: Of Inefficient Firewalls and Efficient Monopolies, June 2008

2337 Sumon Majumdar and Sharun W. Mukand, The Leader as Catalyst - on Leadership and the Mechanics of Institutional Change, June 2008

2338 Ulrich Hange, Tax Competition, Elastic Labor Supply, and Growth, June 2008

2339 Guy Laroque and Bernard Salanié, Does Fertility Respond to Financial Incentives?, June 2008

2340 Adriano Paggiaro, Enrico Rettore and Ugo Trivellato, The Effect of Extending the Duration of Eligibility in an Italian Labour Market Programme for Dismissed Workers, June 2008

2341 Helmut Seitz, Minimum Standards, Fixed Costs and Taxing Autonomy of Subnational Governments, June 2008

2342 Robert S. Chirinko, Leo de Haan and Elmer Sterken, Asset Price Shocks, Real Expenditures, and Financial Structure: A Multi-Country Analysis, July 2008

2343 Wolfgang Leininger, Evolutionarily Stable Preferences in Contests, July 2008

2344 Hartmut Egger and Udo Kreickemeier, Fairness, Trade, and Inequality, July 2008

2345 Ngo Van Long and Bodhisattva Sengupta, Yardstick Competition, Corruption, and Electoral Incentives, July 2008

2346 Florian Baumann, Employment Protection: The Case of Limited Enforceability, July 2008

2347 Alessandro Balestrino, Cinzia Ciardi and Claudio Mammini, On the Causes and Consequences of Divorce, July 2008

2348 Dirk Schindler and Benjamin Weigert, Insuring Educational Risk: Opportunities versus Income, July 2008 
2349 Lammertjan Dam and Ben J. Heijdra, The Environmental and Macroeconomic Effects of Socially Responsible Investment, July 2008

2350 Avner Greif, Contract Enforcement and Institutions among the Maghribi Traders: Refuting Edwards and Ogilvie, July 2008

2351 Helmuth Cremer, Philippe De Donder, Dario Maldonado and Pierre Pestieau, Habit Formation and Labor Supply, July 2008

2352 Francesco Menoncin and Paolo M. Panteghini, The Johansson-Samuelson Theorem in General Equilibrium: A Rebuttal, July 2008

2353 Michael Kaganovich and Itzhak Zilcha, Alternative Social Security Systems and Growth, July 2008

2354 Keith Blackburn, Kyriakos C. Neanidis and M. Emranul Haque, Corruption, Seigniorage and Growth: Theory and Evidence, July 2008

2355 Edward Castronova, A Test of the Law of Demand in a Virtual World: Exploring the Petri Dish Approach to Social Science, July 2008

2356 Harald Badinger and Peter Egger, GM Estimation of Higher-Order Spatial Autoregressive Processes in Cross-Section Models with Heteroskedastic Disturbances, July 2008

2357 Wolfgang Buchholz and Jan Schumacher, Discounting the Long-Distant Future: A Simple Explanation for the Weitzman-Gollier-Puzzle, July 2008

2358 Luca Anderlini, Leonardo Felli and Alessandro Riboni, Statute Law or Case Law?, July 2008

2359 Guglielmo Maria Caporale, Davide Ciferri and Alessandro Girardi, Are the Baltic Countries Ready to Adopt the Euro? A Generalised Purchasing Power Parity Approach, July 2008

2360 Erkki Koskela and Ronnie Schöb, Outsourcing of Unionized Firms and the Impacts of Labour Market Policy Reforms, July 2008

2361 Francisco Alvarez-Cuadrado and Ngo Van Long, A Permanent Income Version of the Relative Income Hypothesis, July 2008

2362 Gabrielle Demange, Robert Fenge and Silke Uebelmesser, Financing Higher Education and Labor Mobility, July 2008

2363 Alessandra Casarico and Alessandro Sommacal, Labor Income Taxation, Human Capital and Growth: The Role of Child Care, August 2008

2364 Antonis Adam, Manthos D. Delis and Pantelis Kammas, Fiscal Decentralization and Public Sector Efficiency: Evidence from OECD Countries, August 2008 
2365 Stefan Voigt, The (Economic) Effects of Lay Participation in Courts - A Cross-Country Analysis, August 2008

2366 Tobias König and Andreas Wagener, (Post-)Materialist Attitudes and the Mix of Capital and Labour Taxation, August 2008

2367 Ximing Wu, Andreas Savvides and Thanasis Stengos, The Global Joint Distribution of Income and Health, August 2008

2368 Alejandro Donado and Klaus Wälde, Trade Unions Go Global!, August 2008

2369 Hans Gersbach and Hans Haller, Exit and Power in General Equilibrium, August 2008

2370 Jan P.A.M. Jacobs and Jan-Egbert Sturm, The Information Content of KOF Indicators on Swiss Current Account Data Revisions, August 2008

2371 Oliver Hülsewig, Johannes Mayr and Timo Wollmershäuser, Forecasting Euro Area Real GDP: Optimal Pooling of Information, August 2008

2372 Tigran Poghosyan and Jakob de Haan, Determinants of Cross-Border Bank Acquisitions in Transition Economies: A Latent Class Analysis, August 2008

2373 David Anthoff and Richard S.J. Tol, On International Equity Weights and National Decision Making on Climate Change, August 2008

2374 Florian Englmaier and Arno Schmöller, Reserve Price Formation in Online Auctions, August 2008

2375 Karl Farmer, Birgit Friedl and Andreas Rainer, Effects of Unilateral Climate Policy on Terms of Trade, Capital Accumulation, and Welfare in a World Economy, August 2008

2376 Monika Bütler, Stefan Staubli and Maria Grazia Zito, The Role of the Annuity’s Value on the Decision (Not) to Annuitize: Evidence from a Large Policy Change, August 2008

2377 Inmaculada Martínez-Zarzoso, The Impact of Urbanization on $\mathrm{CO}_{2}$ Emissions: Evidence from Developing Countries, August 2008

2378 Brian Roberson and Dmitriy Kvasov, The Non-Constant-Sum Colonel Blotto Game, August 2008

2379 Ian Dew-Becker, How Much Sunlight Does it Take to Disinfect a Boardroom? A Short History of Executive Compensation Regulation, August 2008 